\title{
IMPLEMENTASI AHP PEMILIHAN PENYELIA MITRA PETANI DALAM PENGEMBANGAN USAHA AGRIBISNIS PEDESAAN DI KABUPATEN INDRAGIRI HILIR
}

\section{Ilyas}

\author{
Dosen Program Studi Sistem Informasi, Fakultas Teknik dan Ilmu Komputer \\ Universitasi Islam Indragiri (UNISI) \\ J1. Provinsi parit 1 Tembilahan Hulu, Tembilahan, Riau, Indonesia \\ Email : daengilyas01@gmail.com
}

\begin{abstract}
ABSTRAK
Badan Pelaksana Penyuluhan dan Ketahanan Pangan Kabupaten Indragiri Hilir merupakankelembagaan penyuluhan Pertanian dan Ketahanan Pangan di Kabupaten Indragiri Hilir.Bedasarkan pengamatan yang dilakukan oleh peneliti di BP2KP, menunjukkan bahwa pihak BP2KP memiliki sistem evaluasi dan seleksi Penyelia Mitra Tani (PMT) sebelumnya yang hanya menekankan pada siapa yang mengajukan lebih dulu tanpa mempertimbangkan kemampuan dan kesanggupan daripeserta dalam pendampingan dan pelaporan dari setiap Gapoktan yang diawasi itu tadi. Sistem ini tentunya tidak menguntungkan bagi BP2KP ataupun orang yang memiliki keahlian sebagai penyelia mitra tani yang lain, karena kriteria yang digunakan dalam evaluasi dan seleksi penyelia belum menerapkan kriteria yang ada dalam aturan PUAP yang sangat mempengaruhi penilaian dan dapat digunakan untuk menilai kinerja penyelia nantinya. Oleh karena itu, pada penelitian ini, peneliti mencoba untuk merancang suatu sistem evaluasi dan seleksi penyelia mitra tani dengan multi kriteria atau menggunakan kriteria yang sudah ditetapkan dalam PUAP. Metode Analytic Hierarchy Process (AHP) Processmerupakan merupakan sistem pembuat keputusan dengan menggunakan model matematis. AHP membantu dalam menentukan prioritas dari beberapa kriteria dengan melakukan analisa perbandingan berpasangan dari masing-masing kriteria. Hasil perhitungan yang didapat bahwa Alternatifyang menjadi prioritas utama untuk dijadikan sebagai Penyelia Mitra Tani Agribisnis Pedesaan di Wilayah Tembilahan yaitu M. Rafai AH dengan nilai skor 0.363 atau dengan nilai persentase sebesar 36,6\%. Kriteria yang memiliki nilai eigen tertinggi adalah Jenjang Pendidikan Formal Min D3 dengan dilai eigen 0.350 atau 35\%.
\end{abstract}

Kata Kunci : Analytical Hierarchy Process, PMT, BP2KP

\section{PENDAHULUAN}

Badan Pelaksana Penyuluhan dan Ketahanan Pangan Kabupaten Indragiri Hilir merupakankelembagaan penyuluhan Pertanian dan Ketahanan Pangan di Kabupaten Indragiri Hilir. Dalam melaksanakan kegiatan operasionalnya BP2KP juga menagani permasalahan penentuan penyelia mitra tani dalam program PUAP untuk adalah salah satu aspek penting dalam pengawasan dan pendampingan setiap usaha tani atau dikenal dengan nama Gapoktan. Sementara proses pemilihannya dalam sistem pemilihan penyelia mitra tani saat ini masih kurang efisien, padahal proses tersebut tergolong penting untuk dipertimbangkan. BP2KP juga sering merasakesulitan ketika harus melakukan penilaian untuk mendapatkan atau menseleksi 
orang yang mendaftarkan dirinya sebagai penyelia.

Bedasarkan pengamatan yang dilakukan oleh peneliti di BP2KP, menunjukkan bahwa pihak BP2KP memiliki sistem evaluasi dan seleksi Penyelia Mitra Tani (PMT) sebelumnya yang hanya menekankan pada siapa yang mengajukan lebih dulu tanpa mempertimbangkan kemampuan dan kesanggupan daripeserta dalam pendampingan dan pelaporan dari setiap Gapoktan yang diawasi itu tadi. Sistem ini tentunya tidak menguntungkan bagi BP2KP ataupun orang yang memiliki keahlian sebagai penyelia mitra tani yang lain, karena kriteria yang digunakan dalam evaluasi dan seleksi penyelia belum menerapkan kriteria yang ada dalam aturan PUAP yang sangat mempengaruhi penilaian dan dapat digunakan untuk menilai kinerja penyelia nantinya. Oleh karena itu, pada penelitian ini, peneliti mencoba untuk merancang suatu sistem evaluasi dan seleksi penyelia mitra tani dengan multi kriteria atau menggunakan kriteria yang sudah ditetapkan dalam PUAP.

Tujuan yang ingin dicapai dalam penelitian ini yaitu: Untuk memberikan cara pengambilan keputusan yang bersifat objektif tehadap penentuan penentuan Penyelia Mitra Tani dalam PUAP di BP2KP Kabupaten Indragiri Hilir.Untuk merancang sistem informasi yaitu Sistem Pendukung Keputusan penentuan Penyelia Mitra Tani dalam PUAP di BP2KP Kab. Indragiri Hilir. Untuk merancang sebuah sistem pendukung keputusan dengan menerapkan metode Analytical Hierarchy Process. dalam proses penentuan Penyelia Mitra Tani dalam PUAP di BP2KP Kabupaten Indragiri Hilir.

Manfaat yang diharapkan dari penelitian ini adalah: Dengan sistem pendukung keputusan ini diharapkan dapat meningkatkan kinerja dalam pelaksanaan manajemen BP2KP secara efektif dan efisien dalam penentuan Penyelia Mitra Tani dalam PUAP di wilayah Kabupaten Indragiri Hilir. Dengan adanya sistem pendukung keputusan ini, diharapkan dapatmenghemat waktu dalam melakukan seleksi Penyelia Mitra Tani dalam PUAP untuk wilayah Kabupaten Indragiri Hilir. Proses pemilihanPenyeliaMitraTani dalam Pengembangan Usaha Agribisnis Pedesaan Di BP2KP menjadi lebih cepat dalam merekomendasikan kepada pengambil keputusan.

\section{TINJAUAN PUSTAKA}

\subsection{Konsep $\quad$ Sistem $\quad$ Pendukung Keputusan}

Sistem Pendukung Keputusan atau DecisionSupportSystem(DSS) merupakan sistem informasi interaktif yang menyediakan informasi, pemodelan dan memanipulasi data. Sistem itu digunakan untuk membantu pengambilan keputusan dalam situasi yang semiterstuktur dan situasi yang tidak terstruktur, dimana tak seorangpun tahu secara pasti bagaiman keputusan seharusnya dibuat (Kusrini, 2007).

\subsubsection{Sistem}

Suatu sistem dapat terdiri dari sistemsistem bagaian (subsystems). Sebagai misal, sistem komputer dapat terdiri dari subsistem perangkat keras dan subsistem perangkat lunak. Masing-masing subsistem dapat terdiri dari subsistem-subsistem yang lebih kecil lagi atau terdiri dari komponen-komponen. Subsistem perangkat keras (hardware) dapat terdiri dari alat masukan, alat pemroses, alat keluaran dan simpanan luar. Dengan kata lain suatu sistem terdiri dari sejumlah komponen yang saling berinteraksi, yang artinya saling bekerja membentuk satu kesatuan,(Hartono, 2005).

\subsubsection{Sistem Pendukung Keputusan}

Konsep Sistem Pendukung Keputusan pertama kali diperkenalkan pada awal tahun 1970-an oleh Michael S.Scoot Morton dengan istilah ManagementDecisionSystem. Konsep 
sistem pendukung keputusan ditandai dengan sistem interaktif berbasis komputer yang membantu pengambilankeputusan memanfaatkan data dan model untuk menyelesaikan masalah-masalah yang tidak terstruktur (Iwan \& Lirien, 2012).

Sistem pendukung keputusan merupakan suatu sistem interaktif yang mendukung keputusan dalam proses pengambilan keputusan melalui alternatifalternatif yang diperoleh dari hasil pengolahan dat, informasi dan rancangan model (Herdiyanti \& Widianti, 2013).

\subsection{Konsep Model Analytical Hierarchy Process (AHP)}

Pada dasarnya proses pengambilan keputusan adalah memilih suatu alternatif. Peralatan utama AHP adalah sebuah hierarki fungsional dengan input utamanya persepsi manusia. Keberadaan hierarki memungkinkan dipecahnya masalah kompleks atau tidak terstruktur dalam sub-sub masalah, lalu menyusunnya menjadi suatu bentuk hierarki.

Metode AHP adalah metode yang digunakan untuk menilai tindakan yang dikaitkan dengan perbandingan bobot kepentingan antara faktor serta perbandingan beberapa alternatif pilihan, (Ardiyanto, Sasongko, \& Adhy, 2013).

AHP dikembangkan Dr. Thomas L. Saaty dari Wharton School of Business pada tahun 1970-an untuk mengorganisasikan informasi dan judgement dalam memilih alternatif yang paling disukai. Pada dasarnya AHP adalah metode untuk memecahkan suatu masalah yang kompleks dan tidak terstruktur kedalam kelompoknya, mengatur kelompokkelompok tersebut kedalam suatu susunan hierarki, memasukkan nilai numerik sebagai pengganti persepsi manusian dalam melakukan perbandingan relatif dan akhirnya dengan suatu sintesis ditentukan elemen yang mempunyai prioritas tertinggi, (Tominanto, 2012).

Pada dasarnya, langkah-langkah dalam metode AHP meliputi:
1. Mendefenisikan masalah dan menentukan solusi yang diinginkan, lalu menyusun hierarki dari permasalahan yang dihadapi. Penyusun hierarki adalah dengan menetapkan tujuan yang merupakan sasaran sistem secara keseluruhan pada level teratas.

2. Menentukan prioritas elemen: a) Langkah pertama dalam menentukan prioritas elemen adalah membuat perbandingan pasangan, yaitu membandingkan elemen secara berpasangan sesuai kriteria yang diberikan.b)Matriks perbandingan berpasangan diisi menggunakan bilangan untuk merepresentasikan kepentingan relatif dari suatu elemen terhadap elemen yang lainnya.

3. Sintesis. Pertimbangan-pertimbangan terhadap perbandingan berpasangan di sintesis untuk memperoleh keseluruhan prioritas. Hal-hal yang dilakukan dalam langkah ini adalah: a) Menjumlahkan nilai-nilai dari setiap kolom pada matriks. b) Membagi setiap nilai dari kolom dengan total kolom yang bersangkutan untuk memperoleh normalisasi matriks. c) Menjumlahkan nilai-nilai dari setiap basis dan membagikan dengan jumlah elemen untuk mendapatkan nilai ratarata.

4. Mengukur Konsistensi. Dalam pembuatan keputusan, penting untuk mengetahui seberapa baik konsistensi yang ada karena kita tidak menginginkan keputusan berdasarkan pertibangan dengan konsistensi yang rendah. Hal-hal yang dilakukan dalam langkah ini adalah: (a) Kalikan setiap nilai pada kolom pertamadengan prioritas relatif elemen pertama, nilai pada kolom kedua prioritas relatif elemen kedua, dan seterusnya. (b) Jumlah setiap baris. (c) Hasil dari penjumlahan baris dibagi dengan elemen prioritas relatif yang bersangkutan. (d) Jumlah hasil bagi di atas dengan banyaknya elemen yang ada, hasil disebut maks 
5. Hitung cinsistency Index (CI) dengan rumus:

$$
\mathbf{C I}=(\operatorname{maks}-\mathbf{n}) / \mathbf{n}
$$

Di mana $\mathrm{n}=$ banyaknya elemen

6. Hitung rasio konsistensi/consistency ratio (CR) dengan rumus:

\section{$\mathbf{C R}=\mathbf{C I} / \mathbf{R C}$}

Di mana

$$
\begin{aligned}
& \mathrm{CR}=\text { Consistency Ratio } \\
& \mathrm{CI}=\text { Consistency Index } \\
& \mathrm{IR}=\text { Indeks Random }
\end{aligned}
$$

\section{Consistency}

7. Memeriksa konsistensi hierarki. Jika nilainya lebih dari $10 \%$, maka penilaian data judgment harus diperbaiki. Namun jika rasio konsistensi (CI/IR) kurang atau sama dengan 0,1 , maka hasil perhitungan bisa dinyatakan dengan benar. Daftar indeks Random Konsistensi (IR) bisa dilihat dalam Tabel 2.2 berikut:

Tabel 2.1Indeks Random Konsistensi
\begin{tabular}{|c|c|}
\hline Ukuran Matriks & Nilai IR \\
\hline 1,2 & 0.00 \\
\hline 3 & 0.58 \\
\hline 4 & 0.90 \\
\hline 5 & 1.12 \\
\hline 6 & 1.24 \\
\hline 7 & 1.32 \\
\hline 8 & 1.41 \\
\hline 9 & 1.45 \\
\hline 10 & 1.49 \\
\hline 11 & 1.51 \\
\hline 12 & 1.48 \\
\hline 13 & 1.56 \\
\hline 14 & 1.57 \\
\hline 15 & 1.59 \\
\hline
\end{tabular}

\section{METODOLOGI PENELITIAN}

\subsection{Metodologi Penelitian}

Bagan alur metodologi penelitian Sistem Pendukung Keputusanpenentuan Penyelia Mitra Tani dalam PUAP di BP2KP Kabupaten Indragiri Hilirdapat dilihat pada gambar 3.1 berikut:

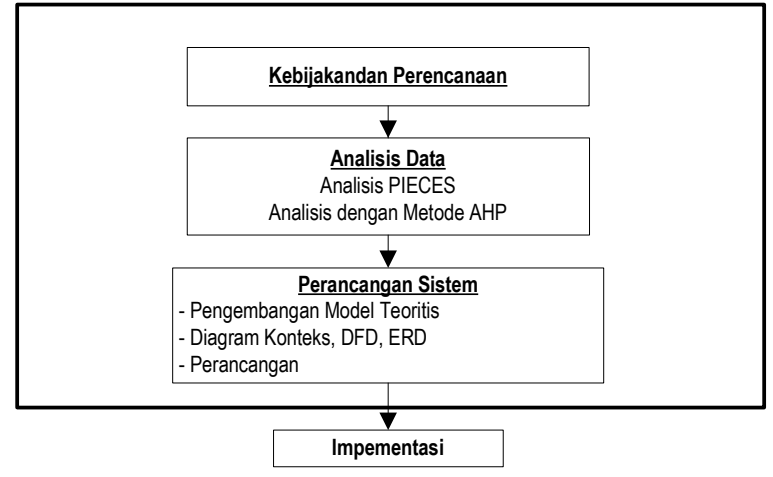

\section{Gambar 3.1Flowchart Penelitian}

\section{PEMBAHASAN DAN IMPLEMENTASI}

\subsection{Pembahasan}

Implementasi sistem pada keadaansebenarnyadikatakan sebagai bentuk penerapan sistem atau penggunaan sistem setelah rancang bangun sistem, melalui tahapan ini nantinya akan diketahui apakah sistem yang telah dibangun benar-benar dapat berjalan sesuai dengan target atau tujuan yang diharapkan atau tidak.

\subsubsection{Struktur Hirarki}

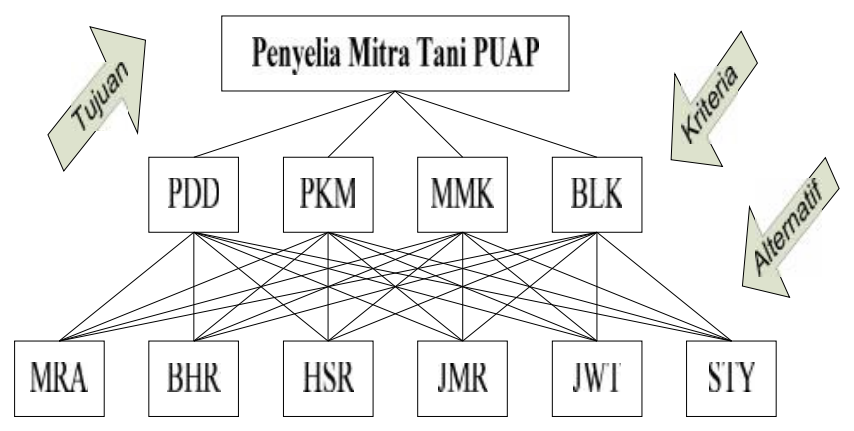

\section{Gambar 4.1 Hirarki Proses Penyelia Mitra Tani PUAP}

Dari Gambar 4.1 diatas dapat diketahui bahwa level pertama merupakan level Tujuan: pemilihan Penyelia Mitra Tani dalam Pengembangan Usaha Agribisnis Pedesaan (PUAP). Level kedua adalah kriteria untuk dapat mencapai tujuan utama. Sementara level ketiga merupakan alternatif 
dari yang digunakan, untuk level kriteria dan alternatif dapat diketahui sebagaimana yang dijelaskan pada langkah pertama.

\subsection{Implementasi}

Tahapan implementasi menceritakan keadaan sistem pendukung keputusan yang telah dibangun, sehingga akan diketahui bagaimana proses kerja dari sistem pendukung keputusan tersebut. Dan memberikan penjelasan-penjelasan dari setiap tampilan atau bentuk dari layar monitor sebagai interface antara user dengan sistem yang sudah dirancang pada aplikasi ini. Berikut merupakan penjelasan-penjelasan dari setiap userinterface aplikasi sistem pendukung keputusan ini:

1. Perbandingan Kriteria

Perbandingan kriteriaadalahform yang digunakan untuk menginputkan hasil quisioner dengan skala perbandingan antar kriteria yang digunakan untuk melakukan proses perhitungan AHP pada sistem ini yang sebelumya telah dilakukan rekap quisioner. Pada perbandingan inilah yang nantinya digunakan untuk mengetahui hasil perangkingan pada proses penentuan prioritas global untuk proses pemilihan penyelia mitra tani agribisnis pedesaan di BP2KP.

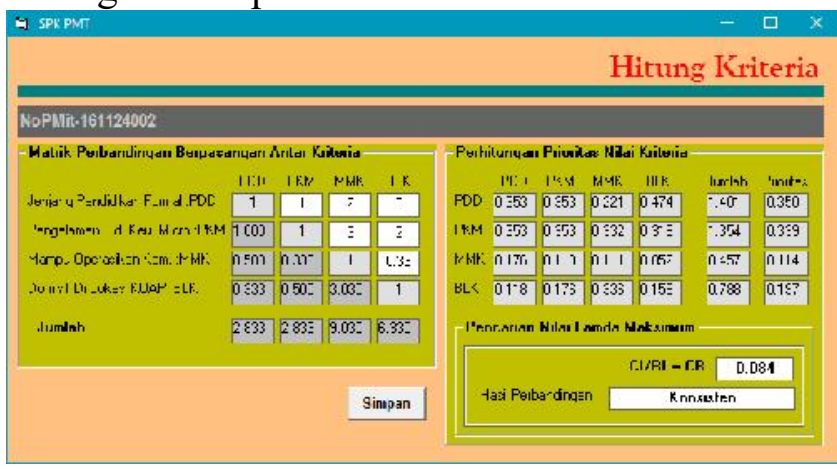

Gambar 4.2Perbangdingan Kriteria

Form perbandingan kriteria ini juga menampilkan hasil perhitungan prioritas nilai kriteria sehingga diketahui bobot prioritas dari setiap kriteria, selain itu juga pada form memperlihatkan nilai konsistensinya. Untuk melanjutkan perbandingan antar alternatif dilakukan dengan menekan tombol simpankemudian akan menampilkan menu utama kemudian pilih menu perhitungan, pilih menu perbandingan alternatif.

\section{Perbangdingan Alternatif}

Perbandingan alternatif adalah form yang digunakan untuk melakukan proses perhitungan AHP untuk alternatif berdasarkan hasil rekapitulasi quisioner, form ini jumlahnya sesuai dengan jumlah kriteria yang ada, karena untuk memberikan keputusan maka setiap alternatif harus dilakukan perbandingannya dengan berdasarkan kriteria yang ada. Proses entri yang ada pada form ini sama dengan form kriteria yaitu cukup inputkan nilai hasil quisioner pada kolom matrik perbandingan berpasangan antar alternatif kemudian tekan tombol lanjut untuk melakukan perbandingan alternatif berikutnya.

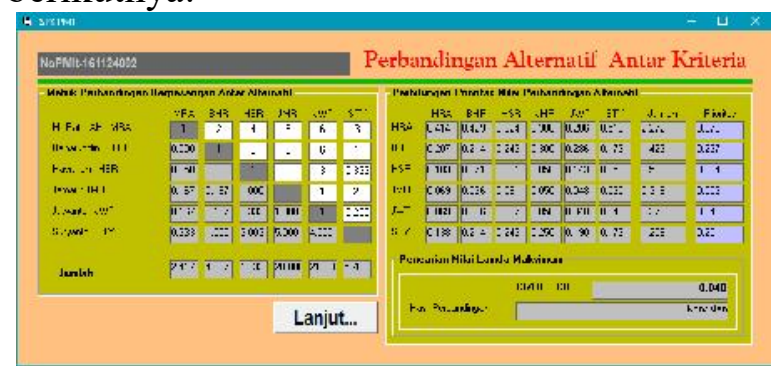

Gambar 4.3Perbangdingan Alternatif

Proses perbandingan antar alternatif berdasarkan kriteria, hal pertama yang dilakukan memilih alternatif yang akan dibandingkan. Pada kasus ini ada enam alternatif yang dibandingkan untuk setiap perbanndingannya. Setelah dilakukan pengisian matrik perbandingan pada tombol lanjut dalam keadaan di pilih makan akan menampilkan proses perbandingan berikutnya berdasarkan criteria yang ada sampai proses perbandingan alternatif antar criteria selesai maka selanjutnya dapat dilakukan perhitungan prioritas global.

\section{Prioritas Global}

Prioritas globalmenunjukkan nilai bobot dari dari setiap pebandingan ataupun hasil dari perkalian matriks yang telah dilakukan sebelumnya, baik nilai bobot 
prioritas kriteria maupun bobot prioritas perbandingan antar alternatif berdasarkan kriteria. Dari nilai-nilai bobot prioritas alternatif yang ada dikali matrikkan dengan nilai bobot prioritas yang ada sehingga mengasilkan suatu nilai yang disebut juga nilai perangkingan untuk setiap alternatif. Nilai-nilai tersebut digunakan sebagai bobot untuk menentukan alternatif mana yang dapat dijadikan sebagai rekomendasi dalam sistem pendukung keputusan ini. Hasil rekomendasidiperlihatkan dalam bentukrangking dan juga merupakan informasi yang ada pada formini. Alternatif yang memiliki nilai tertinggi dijadikan sebagai bahan rekomendasi keputusan pemilihan penyelia mitra tani agribisnis pedesaan di Badan Pelaksanaan dan Penyuluhan Ketahanan Pangan (BP2KP) Tembilahan.

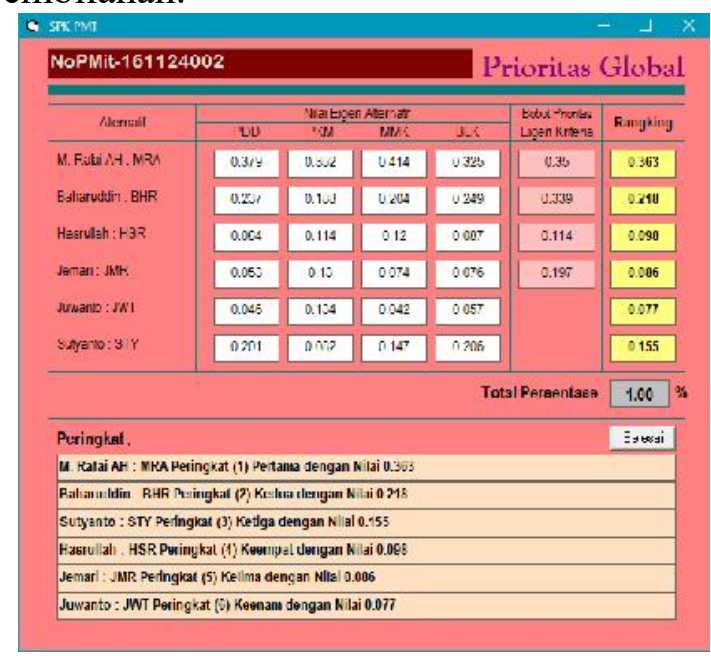

Gambar 4.4Prioritas Global

Hasil perhitungan yang telah dilakukan sebelumnya maka dapat diketahui bahwa urutan prioritas global/peringkat keputusan pemilihan penyelia mitra tani pada BP2KP Tembilahan sebagai berikut:

1. M Rafai AHsebagai Peringkat pertama dengan nilai 0.363 atau $36,3 \%$

2. Baharuddin sebagai peringkat ke dua dengan nilai 0.218 atau $21,8 \%$.

3. Sutyanto di peringkat ke tiga dengan nilai perbandingan 0.155 atau $15,5 \%$

4. Hasrullah berada diperingkat ke empat dengan nilai 0.098 atau $9,8 \%$
5. Jemari berada diperingkat ke lima dengan nilai 0.086 atau $8,6 \%$, dan

6. Peringakat terakhir yaitu Juwanto dengan nilai 0.077 atau $7,7 \%$.

Melihat dari urutan rangking yang diperoleh dari hasil perhitungan dengan metode AHP dalam sistem pendukung keputusan ini, maka yang layak atau yang dijadikan rekomendasi untuk penyelia mitra tani agribisnis pedesaan yaitu M. Rafai AH dengan nilai skor 0.363 atau dengan nilai persentase sebesar $36,3 \%$.

\section{KESIMPULAN DAN SARAN \\ 5.1 Kesimpulan}

Berdasarkan hasil penelitian diperoleh pemilihanpenyelia mitra tani agribisnis pedesaan di BP2K Tembilahan menggunakan metode Analytical Hierarchy Process (AHP), maka dapat diambil beberapa kesimpulan yaitu:

1. Hasil perhitungan yang didapat bahwa Alternatifyang menjadi prioritas utama untuk dijadikan sebagai Penyelia Mitra Tani Agribisnis Pedesaan di Wilayah Tembilahanyaitu M. Rafai AH dengan nilai skor 0.363 atau dengan nilai persentase sebesar $36,6 \%$.

2. Pada penelitian ini, setelah dilakukan perhitungan maka kriteria yang memiliki nilai eigen tertinggi adalah Jenjang Pendidikan Formal Min D3 dengan dilai eigen 0.350 atau $35 \%$.

3. Berdasarkan analisa yang dilakukan, metode Analytical Hierarchy Process (AHP) dapat digunakan sebagai metode dalam Sistem Pendukung Keputusan untuk pemilihanPenyelia Mitra Tani Agribisnis Pedesaan di BP2KP Tembilahan.

\subsection{Saran}

Berdasarkan hasil kesimpulan dari sistem pendukung keputusan pemilihanpenyelia mitra tani di BP2KP Tembilahan, bahwa adapun saran yang diberikan yaitu: 
1. Penelitian ini dapat dijadikan sebagai bahan rujukan oleh pimpinan BP2KP Tembilahan dalam memilih Penyelia Mitra Tani Agribisnis Pedesaan berdasarkan kriteria yang telah ditetapkan.

2. Penelitian ini hanya menganalisa dan menguji hasil perhitungan metode AHP untuk pemilihan penyelia mitra tani agribisnis pedesaan di BP2KP Tembilahan dengan menggunakan enam alternatif sebagai acuan dalam penilaian, untuk itu diharapkan kepada peneliti selanjutnya yang menjadikan penelitian ini sebagai rujukan agar dapat melakukan perancangan sistem pendukung keputusan yang lebih baik yang dapat digunakan untuk melakukan penilaian terhadap pemilihan penyelia mitra tani agribisnis pedesaan di wilayah tembilahan.

\section{DAFTAR PUSTAKA}

Ardiyanto, H., Sasongko, P. S., \& Adhy, S. (2013). Sistem Pendukung Keputusan Pemilihan Perumahan Menggunakan Metode AHP Berbasis WEB (Studi Kasus CV. Wisma Anungkriya Demak). Join , 1-8.

Hartono, J. (2005). Pengenalan Komputer. Yogyakarta: Andi.

Herdiyanti, A., \& Widianti, U. D. (2013). Pembangunan Sistem Pendukung Keputusan Rekrutment Pegawai Baru di PT. ABC. Jurnal Ilmiah Komputer dan Informatika (KOMPUTA) , 49-56.

Iwan, R., \& Lirien, O. (2012). Sistem Pendukung Keputusan Pemilihan Karyawan Berprestasi Berdasarkan Kinerja Menggunakan Metode Analytical Hierarchy Process. Seminar Nasional Informatika (pp. -). Yogyakarta: -.

Kusrini. (2007). Konsep dan Aplikasi Sistem Pendukung Keputusan. Yogyakarta: And.
Tominanto. (2012). Sistem Pendukung Keputusan Dengan Metode Analytical Hierarchy Process (AHP) Untuk Penentuan Prestasi Kinerja Dokter Pada RSUD. Sukoharjo. INFOKES , $1-15$. 